\title{
MOCERA TASI RITUAL AMONG THE WOTU COMMUNITY IN EAST LUWU (The Maslahat Perspective)
}

\author{
Zulhas'ari Mustafa \\ UIN Alauddin Makassar \\ Jln H. M. Yasin Limpo No. 36 Samata Gowa \\ Email:mzulhasari@gmail.com
}

\begin{abstract}
This article deals with the explanation of local celebration called mocera tasi performed by the ethnic Wotu community in East Luwu District. The focus of the research is closely related to the values understood by the Wotu ethnic community, in relation to the ritual of mocera tasi. Such Values, according to Community understanding, were derived from the cultural practices within the community. The ritual, in addition, was carried out by the Wotu community in order to legitimize the leadership of the Macowa Bawalipu as Wotu traditional leaders, to expressing gratitude to Allah SWT, and to rejecting reinforcements. The mocera tasi rituals as a ritual for ratifying traditional leaders are classified as adat rituals. Mocera tasi, in addition, as an expression of gratitude and refusal of reinforcements is also classified as folk ritual. The benefit to be achieved in the ritual of mocera tasi is linked to the maintenance of the benefit of Nasab (family blood) and wealth. The level of the benefit of the ritual of mocera tasi is at the level of hajizyyat
\end{abstract}

Key words: Mocera Tasi, Rituals, Maslahat, Culture

\section{Introduction}

Both Religion and culture appear in the reality of people's daily lives. The relation of Religion and culture in people's lives can be illustrated as two sides of a coin. Religion 
and culture can go hand in hand, criticize each other, and can further influence each other. The linkages of Islamic and cultural entities have triggerred new changes and problems that may affect the life of their adherents (Kuntowijoyo, 2001: 196). Cultural references of Islamic societies contain descriptions over dialogue, negotiations, struggles, and tactics between the relation of Islam and culture. The process of dialogue, negotiation, struggle, and strategy in Islamic relations and culture will gradually continue throughout the history of mankind. Not few problems were born and successfully colored the process of Islamic and cultural dialects, starting from the issue of socio-cultural practices up to theological-normative issues. The clarity in viewing the phenomenon of contact between Islam and culture is considered as important to set both points in such strategic position.

A more proportional approach is expected to apply in order to appreciate the phenomena of the relation between Islam and culture. That proportional approach is basically established as a reflection of the nature of Islamic teachings, called rahmatan li al-älamin. The nature character of Islamic teachings delivered by the prophet Muhammad peace be upon him. In this case, the so-called rahmatan li al-alamin that will experience an applied problem as the approach towards the relation of Islamic and culture is always institutional-based approach. According to the historical study of Abdurrahman Wahid, revealing that the attitude of Muslims in facing the current era is divided into two groups. First, groups using a 
cultural approach, and second, those carrying out institutional approaches. Cultural groups prioritize the presence of Islamic culture in the practice of society, while institutional groups consider Islam as an alternative ideology put between the Western civilization and imperialism (Wahid, 2005: 68-70). Not many from the Islamic groups use the religious definition, which emphasizes the institutional side as an approach in appreciating the tight relations between Islam and culture. Institutional approaches can result in some problems related to humans as religious followers in facing social problems. The definition of religion, as a set of rules for the relationship between humans and God, humans and humans, and humans and their environment limits the role of religion for humanity (Wahid, 2005: 71-73). Institutionalbased religious perspectives can furthermore ignore the social-cultural aspects that influence humans' life. At this point, neglecting social-cultural aspects will affect the gap between religious teachings and social-cultural practices within the society.

The relation between Islam and culture can be traced back through the perspective of localization, to neglect the concept of syncretism. The localization paradigm regards that Islam has suffered a localization process. Local culture is influential in Islamic nuanced practices. The practice of community culture, that is claimed to have Islamic nuances, absorbs local traditions or culture, not local culture that absorbs Islamic values (Wahid, 2001: 111). The localization process shows that Islamic elements positioned as new 
religion must find their land in the local culture. The Transplants occur with through meeting of values that are considered similar with each other, and deepen so far with the formed traditions. The born traditions through the localization process are essentially the absorption of Islam towards local traditions, so that the Islamic tradition appears as an outer layer covering the local beliefs.

The landscape of Islamic values and local culture illustrates a significant change in the form of shifting of local traditions into local Islamic traditions, or Islamic traditions in the context of locality (Zada, et al, 2003: 9-10). Such change does not neglect the fact that the cultural environment has an influence on one's religious expression. The Character of one's religious behavior can be derived from the influence of geographical conditions, climatology, and topography of a region. The location of the residential area also affects the physical, mental, and character of its inhabitants in the community. The reality of environmental influences causes a thesis saying that a certain environment of a group of people has an influence on their religious habits (Ibn Khaldūn, 2004: 46). The mentioned thesis is not concerned to refute the universality aspects of a religion, particularly Islam. The thesis is otherwise intended to state that the diversity of applications of of a religion's universal principles occurs at the level of reality. Diversity, moreover, refers to the implementation of a religious teaching at the technical level. The reciprocal influence between Islam and local culture is found in practical forms of religion manifestations and cultural teachings. 


\section{Zulhas'ari Mustafa}

Gloves, skullcaps, prayer mats, and prayer beads are such examples that can be easily appointed. The use of sarongs, skullcaps, prayer mats or prayer beads cannot be claimed as universal. However, the existence of sarongs, skullcaps, prayer mats or prayer beads has successfully become a symbol of Islam in the cultural local area.

Although Islam has been accepted by the majority of Indonesian people, such tensions in dialogue between Islam and locality still occur once in a while. The conflict with local values describes a group of Islamic societies that use violent idioms to judge the practice of certain ritual in a society. The judgment of certain groups on the practice of ritual has born particular resistance from the ritual society. One ritual that often received negative criticism from a group of Islamic societies is the maccera tasi. The practice of such ritual is carried out by the Buginese community living in coastal areas. The macera tasi ritual is carried out as an expression of gratitude to the Creator, who has overloaded natural wealth for the welfare of mankind. The Wotu community in East Luwu District recognized the mocera tasi ritual as a different phrase that has similarities to the maccera tasi tradition.

The ritual of mocera tasi for the people of Wotu is not solely carried out as an expression of gratitude to the Creator, but is further related to the presence and survival of all creatures of the Creator. Mocera tasi, in addition, as a cultural instrument is present in the practice and memory of the community regarding sacred values and life beliefs, which has taken a very long period of time. The rapid and massive 
changes within the contemporary society cannot prevent the inheritance of the ritual from one generation to the other generation. The endurance of the ritual mocera tasi in cultural practice shows the widen of the benefits for the Wotu community. The benefits of the mocera tasi rituals are important to be investigated though a research. A maslahat perspective will be used to analyze the concepts and practices of mocera tasi ritual.

The focus of the existing research was related to the social and cultural life of the Wotu community, especially the ritual of mocera tasi. The research explored the understanding and belief of the Wotu community towards the ritual of mocera tasi. The practice of mocera tasi at the cultural level is experiencing a discursive process. Mocera tasi is practiced, criticized, and defended, both from the internal and external groups within the Wotu community. A study based on the use of Maslahat perspectives was undertaken as an academic effort using Islamic legal thinking to appreciate the practice of democracy in the Wotu community. The choice of the maslabat perspective is further intended to put the conversation om mocera tasi at the level of public benefit.

This research aimed to explore the understanding of the Wotu community in the context of mocera tasi ritual, to explore the reality depth of mocera tasi in the context of social and cultural relations of the community, and to develop a maslahat perspective according to Shari'a objectives for related elements related to mocera tasi ritual. The advantage of this research is classified into academic, sociological, and 
government advantages. Academic benefits are expected to give support in academic development, the raise of discussion atmosphere between Islamic law and local values, and enrichment of knowledge in the field of Islamic law. The sociological advantage of this research expects such strengthening of the community's understanding towards the ritual of mocera tasi, provides constructive information about the rituals of mocera tasi, and delivers a message that culture is a social modal of cultural community, that plays an important role in the continuity of nation. The particular advantages for the government are expected to be an academic input in policy making, especially regarding the culture and rights of local communities.

\section{Literature Review}

There were several previous studies providing orientation for the continuation of this existing study. Iriani wrote a research entittled Maccera Tasi 'Sebagai Ritual Nelayan di Luwu (2015). Her focus of study was ceremony procession of Maccera Tasi, the expression of the ceremony symbols, and the function of the maccera tasi ritual. The results of the study illustrated several things regarding the philosophical background of the ritual, the preparation and the activity, the meaning of the ceremony for the Luwu people, and the values in that ceremony.

Kamaruddin Mustamin, moreover, discussed a research on Macceraq Tappareng: The Study of Mysticism on Lake Traditions in Attoriolong of the Buginese Community in Wajo District (2016). The study aimed to investigate the 
mystical practices of the Buginese people of Wajo District on the coast of Tempe Lake in before Islamic period, to know the mysticism in the macceraq tappareng ritual, and the pattern of relations between macceraq tappareng and Islam.

Abu Haif also carried out a research related to the Rituals in the Tradition of Mappanretasi within Buginese Fishermen in Pagatan, Tanah Bumbu Regency, South Kalimantan; Acculturation of Islam with Local Culture (2017). The research objectives are; first, to describe and analyze the background of the existence of the Buginese tribe and mappanretasi ritual in Pagatan. Second, to describe and to analyze the development of procedures for implementing the mappanretasi ritual. Third, to describe and to analyze the transformation process of Islamic elements in the mappanretasi ritual through the theory of acculturation.

Syakerani conducted a research on the Ceremony of Mappanre Ri Tasie in Buginese Community in Kusan Hilir Pagatan Kotabaru Regency (2000). Such study discussed traditional ceremony of Mappanretasi from aspects of local culture. Research results explored the mystical understanding of the community regarding the spirits of the ancestors. The study revealed the symptoms of syncretism in that aforementioned ritual carried out by Buginese Pagatan fishermen. The referred syncretism in the study was a mixture of Islamism, animism, dynamism and Hinduism.

Hanafi Baidawi conducted a research entitled The construction of variety of Fishermen: A study on Rokat Tase Ritual in Branta Tlanakan Village Pamekasan Madura (2015). 


\section{Zulhas'ari Mustafa}

The research discussed the structure of thinking of fishermen communities. At this point, religious systems were used as the daily work ethic. The work ethic of the fishermen relates to the expectations regarding the success activity of sailing, the overloaded results of fishing, and harmony of the soul.

Ahmad Kamal wrote the Social Construction The Meaning of the Remembrance Ceremony of Buginese Pagatan Fishermen Citizens (2011). The study discusses mappanretasi as the ritual of pagatan fishermens in the context of the presence in social construction.

Several studies have discussed such ritual practices that have similarities with mocera tasi ritual, for instance, a research on mocera tasi, maccera tappareng, and the research on mappanre tasi. The aforementioned studies, on average, have not directly investigated Mocera tasi ritual in Wotu community. The used analysis has not yet used the maslahat perspective. The difference between the previous research and the existing research lies in the ritual moment and the benefit of maslahat perspective.

Spirit of Shari'a concerns the concepts and actions in order to preserve the benefits of religion, soul, mind, and wealth. All efforts to preserve the benefit of the five main aspects are then called mașlaḥah. Any ideas or actions that eliminate the five main aspects are classified as mafsadat or mudarat (damage). In this case, refusing or eliminating damage/mudarat means presenting maslahat at the same time (al-Ghazali: 482). Maslahat, according to Imam alGhazālī,refers to the suitability of maslahat or benefits with the 
aim of the presence of the Shari'a (Opwis, 2017: 7-32). The realization of the objectives of Shari'a, according to Saif alDin al-Āmidī, can exist in the form of fulfillment of benefit, loss of damage/mudarat, or the combination of maslahat fulfillment and loss of damage (al-Āmidī, $1338 \mathrm{H}$ : 339). Maslahat is always composed of al-kulliyyat al-khams, including the maintenance of the benefit of religion, soul, mind, and wealth. Maslabat is built through the concept of ūarūriyyat, ḥājiyyyat, and taḥsīniyyat (al-Syāțịīi: 3-8). Maslahat will always contain one of the two sides, either producing benefits or avoiding damage. Furthermore, Sa'īd Ramaḍān alBūṭ̂ built the argument that any containing the value of benefits can be called maslahat. Benefits can be generated through al-jalb or al-tahșil. Al-jalb, on one hand, involves direct actions that have benefits. Al-tahșill, on the other hand, is concerned with the presence of benefits as an implication of an effort or action (al-Būțī, 1992: 27). Maslahat dan mudarat cannot be present simultaneously, because maslahat and mudarat are extremely opposing with each other. If the maslabat is present, then there is no damage/mudarat. If the damage is present, then the maslabat is getting lost.

\section{Research Methodology}

This study was conducted through a field research that used a qualitative research model. The research took place in Lampenai Village and Bawalipu Village in Wotu District, East Luwu Regency. Cultural studies were the main approach of this research as they have triggered an awareness that reality 


\section{Zulhas'ari Mustafa}

has been constructed. The reality, according to cultural studies, is understood and ignored, discussed and forgotten, turned on or turned off, managed or damaged, utilized or avoided based on the construction system circulating among the citizens (Agger, 1992: 2-3). The research approach did not exclude various complementary perspectives from various scientific bases. The variety of perspective on social humanities are to be used as an approach that supports the existing research.

Research data was obtained from sources, fields, and documents related to the focus of the study. Source of information in this case was positioned as research informants. The desicion of informants was done by purposive sampling technique, which can develop into snowball sampling. Extracting data from informants was done through unstructured and semi-structured interviews. field data was obtained through participatory and unaparticipatory observation. Data was also extracted through written documents from various parties, especially those involved directly with the ritual of mocera tasi.

\section{Mocera tasi and Wotu Ethnic Community Sacred Knowledge}

Conceptual configuration of the mocera tasi ritual ${ }^{1}$ is in the construction of the collective memory of the Wotu

${ }^{1}$ Macera tasi is a phrase consisting of the words maslahat and tasi. Maslahat is derived from the word cera berimbuhan mo. Cera means that the blood that gets the infusion means to bleed. Tasi means sea. The meaningful phrase means the process of bleeding in the sea. 
community. Community's memory consists of understandings, meanings, and interpretations towards the mocera tasi heritage. The belief of the local community of Wotu on the power of Pua Lamoa has been confirmed by a monotheistic view of Islamic teachings. The absorption of Islamic theology is described by M. Amin Anggoe's explanation in local language as follows:

“Ani sara mocera tasi sitonganna situju-tuju badua sara'E. Anu motaE sara'E Allah swt. sango-sangona Pua waddiE isompa, pettu to dua tappa na to duluE. Ada ipauE ba wina. To iduluE motae Pua Lamoa, agamaE motae Allahu Ta'ala. Jaji yamassanna atekaE lagau-gauE ilara mocera tasi edo sia lasalai agamaE."(Anggoe, 2018)

Meaning:

"The tradition of mocera tasi basically has conformity with sharia teachings. If sharia calls Allah Almighty, it states that he is the only God that can be worshiped, then the ancient generation of Wotu trusted the same God ... (just a different terminology). The ancient Wotu generation called Pua Lamoa, while religion (Islam) called Allah Ta'ala. So, everything related to intention, intention and practice in the preaching cannot be said to violate religious teachings."

The awareness of the existence of the only God basically became the core of Wotu's community belief since its existence. The Wotu community as part of the ethnic archipelago have built a theological view based on monotheistic beliefs. Belief in the only one God has not changed since the time of ancient Wotu to modern times. Such changes only occur in the mention of names for the One 
and Only Substance (God). The practice of worshiping God also changes with the presence of new religions, especially Islam. Islamic Sharia is present to replace the worship of Wotu community practices, but does not eliminate local traditions of mocera tasi. The impression of the old culture remains in the tradition of society, but the religious teachings that are adhered by the community can affect changes to cultural practices. Mocera tasi as a representation of the ritual practices of the previous Wotu community is still carried out until modern times. Even though the Wotu community experienced religious conversion from the time of molamoa until the period of Islam, mocera tasi is always present continually in the practice of community culture (Tuse, 2018). ${ }^{2}$ The endurance of the practice of transcendence over time proves the strength of tradition rooted in people's beliefs and understanding. Inheritance of the rituals of generation over generation do not experience obstacles due to religious conversion in the community. The power of democracy lies in the consistency of theological and cosmological values that motivate ritual practice. The Wotu community's understanding of mocera tasi has never been separated from their belief in God. Although there are differences in the mention of names for God due to religious conversion, but those that are named remain the same. Theological beliefs bind to the understanding of society's cosmology which

${ }^{2}$ Legal rituals can occur at intervals of more than three years. The ritual ritual according to an elderly Wotu ethnic community was held in 1943, 1953, 2009, and 2016. 
lowers ideological awareness to maintain and pass on the rituals of success from generation to generation. Theological, cosmological and ideological links fill the configuration of Wotu's public understanding of the ritual of mocera tasi. The memory of the people of Wotu still keeps an impression of the mention of the name of God starting from the designation Pua Lamoa, Dewata SeuwaE, to the term Puang Allabu Ta'ala. The term Pua Lamoa is a representation of God's name for the local beliefs of the early Wotu people in the Kalaena Valley.

\section{Mocera tasi in Wotu Community Beliefs Building}

The early ethnic ancestors of Wotu were named To Ampalangi Pua Lampenai introduced the teachings of molamoa (Laluka, 2018) ${ }^{3}$ who recognized Pua Lamoa as the One and Only God and ruler of the universe. Molamoa teachings have not recommended a special system of worship as a series of devotion to the Creator. The ancient Wotu community was introduced to the teachings of monotheism and the nature of God's power in relation to the surrounding environment. The introduction of Sang Maha Tunggal (the only God) without being accompanied by special guidance for worshiping the Creator triggered people to look for certain patterns and ritual forms as expressions of surrender to the Creator. The ritual patterns and forms of surrender to the creator are associated with origin and nature as a source of livelihood. The origin is related to the early humans and their presence. The early

${ }^{3}$ Molamoa is a local belief held by the ancient Wotu ethnic community and Pamona. Molamoa beliefs embrace the theology of monotheism. Pua Lamoa is called the name for the One and Only God. 
humans for the Wotu ethnic community had heritage located around the mulatau site (Putea, 2018). ${ }^{4}$ The heritage of mulatau is located in the Bilassa Lamoa area at the foot of Mount Lampenai. The location of heritage mulatau is believed by the ethnic community of Wotu as the starting place for Wotu's ancestors to build their kinship system and civilization. There is one name stored in the memory of the Wotu people regarding the ancestor before the Batara Guru. To Ampalangi ${ }^{6}$ Pua Lampenai began to build the community, teaches cultivation, and decreed the teachings of divinity in the region called Bilassa Lamoa. The position of Bilassa Lamoa is the main center of ancient Wotu ethnic life. Life activities that began in Bilassa Lamoa spread to several surrounding areas and formed new settlements. Bilassa Lamoa as the place to start the Wotu community is slowly turning into a sacred place that becomes the knot of Wotu's ethnic relations. Wotu ethnic groups regularly visit mulatau sites or to commemorate early humans who have built communities, taught life

${ }^{4}$ Mulatau is an association of Bugis people and also Wotu against early humans as the forerunner to forming ethnic communities.

${ }^{5}$ Bilassa Lamoa in Indonesian means a garden or farmland gift from the Creator, Pua Lamoa. Bilassa Lamoa is $5 \mathrm{~km}$ from the city of Wotu. Bilassa Lamoa is believed to be the first place for the Wotu ethnic community to build a life order.

${ }^{6}$ To Ampalangi is believed to be the first ancestor of the Wotu ethnic community before the arrival of Batara Guru. To Ampalangi was appointed as the ethnic leader of Wotu with the title Pua Lampenai. The use of the Pua Lampenai title for Wotu ethnic leaders runs for two generations. The Wotu ethnic community gave the Pua Macowa title to traditional leaders after Pua Lampenai. 
structures, and introduced the creator. The activity was initially dedicated to commemorating its origins and turned into a ritual that could be identified as a practice of the tradition of molamoa. The mulatau site or turned into a sacred knot for the ancient Wotu ethnic community. The settlement of Bilassa Lamoa at the foot of Bukit Lampenai developed into a center for the activities of the life of the ancient Wotu ethnic community. Pua Lampenai acts as the spiritual leader and worldly leader of the ancient Wotu ethnic community (Razak, 2016; 42-44). The mammoth belief believes in the existence of Pua Lampenai as a representation of Pua Lamoa on earth. In general, Pua Lampenai has the task of providing guidance for the welfare development of the ancient Wotu community, both physically and mentally. The naming of Pua Lampenai as the traditional leader of the Wotu community is estimated to last until the second generation. The name Pua Lampenai was replaced with Macowa Bawalipu or Pua Macowa Bawalipu as the Wotu ethnic traditional leader. The leadership of Pua Lampenai or Macowa Bawalipu was passed through the ritual of mocera tasi.

The swear of the leader of the ancient ethnic community of Wotu in the ritual of mocera tasi brought spiritual and worldly consequences to the leader. The spiritual consequences imposed a spiritual, moral, and ethical example of Pua Lampenai or Macowa Bawalipu. The worldly consequences impose responsibility for the protection and service of all natural rights, especially the Wotu ethnic community. Spiritual exemplary places the figure of a 


\section{Zulhas'ari Mustafa}

traditional leader as a guide to trust in the only God, a guide to the introduction of the essence of the only God, and a servant for ritual activities. A Moral example of traditional leaders is demonstrated through personal integrity as the holder of community leadership. Ethical example from the figure of the traditional leader, in addition, refers to the respect of others and the proportionality of attitude to life. The responsibility of worldly leadership requires indigenous leaders to be fair and sincere in building a life order, both in relations between human beings and between humans and their surrounding environment. The entire burden of cultural leaders who were ratified through the process of independence has theological consequences in the teachings of molamoa. An indigenous leader who is negligent of his leadership responsibilities will be lowered from the leadership and expelled from the protection of the virtues of Pua Lamoa. Individuals who are expelled from the protection of the virtues of Pua Lamoa will experience the horrors of death and the misery of life in the realm of $W$ aliala. The mocera tasi ritual has become a mechanism for authorizing the leaders of the Wotu ethnic community from the first generation to the contemporary generation. The practice of tolerance for the ratification of traditional leaders can be sustained from time to time because theological content has tied the collective memory of the community to the ritual of mocera tasi.

\section{Mocera tasi, Kinship, and Wealth of Wotu's Ethnic Society}


Mocera tasi is a ritual of the Wotu community in the form of dropping the blood of animals in the middle of the sea as a moment of ratification of the traditional leadership of Pua Macowa Bawalipu, rejecting reinforcements, or expressing gratitude to God Almighty for the abundance of marine products. The moment of ratification of the Pua Macowa Bawalipu is related to the gau pangngadarra (adat ritual). The moment of resistance and thanksgiving is called gauna tomatabbae (folk ritual) (Syakhiruddin, 2018). Mocera tasi in the context of adat rituals is relates to the ratification of the position of spiritual and worldly leadership of Pua Macowa Bawalipu. Worldly and spiritual leadership places Pua Macowa Bawalipu as an outward knot of the kinship of the Wotu ethnic community. The Pua Macowa Bawalipu outward knot symbol reminds the public of the origin of kinship or Nasab. Pua Macowa is the node of all Wotu ethnic relations. The mocera tasi ritual became a memorial to the origin and universe through the ratification of the leadership of Pua Macowa Bawalipu. Mocera tasi in the context of folk ritual is related to the source of human livelihood. The sea is a wealth, that is very valuable for maritime society. Sea for maritime society has a vital role in all aspects of life. Through mocera tasi, the Wotu community traced the emotional link between humans as beneficiaries and the sea as a source. The origins of Nasab and the sea as a source of wealth are the core concepts of determining the axis of the maslahat. Identification of problems in the rituals of prayer can be done through the introduction of the significance of social problems in relation 
to everyday life, direct observation to ensure the manifestation of maslahat in reality, customary considerations of the urgency of the masses, and the relevance of contentious issues with related scientific perspectives with the problem of the Shari'a.

The mocera tasi ritual has an interest in the effort to trace the origins of Nasab (blood family) and wealth (Putea, 2018). The introduction of Nasab will give birth to the solidity of the kinship system in a society. The positive aspect of the solidarity of the kinship system is to foster solidarity between members of the community (Ministry of Religion, 2016: 516). ${ }^{7}$ Solidarity encourages empathy for others, both fellow kin groups and other kinship groups. Acts of empathy for others can be a tangible help (Ministry of Religion, 2016: 106). ${ }^{8}$ Lightens the burden of others who are afflicted by calamity (Ministry of Religion, 2016: 24) ${ }^{9}$, or warn each other about

${ }^{7}$ Solidarity has a close meaning with ukhuwah in Islamic teachings. Solidarity in the context of the Wotu community is related to ukhuwah insāniyah, ukhuwah wataniyah, and ukhuwah diniyah. Solidarity in Islam is supported by the text QS al-Hujurat / 49: 10 which states that every believer is a brother ...

${ }^{8}$ Allah Almight ordered help to help in kindness, as mentioned in Surah al-Maidah / 5: 2: "... And help you in (doing) virtue and piety, and do not help in sinning and transgression. And fear Allah, verily Allah is severe in His torment.

9Surah al-Baqarah / 2: 155-156 states "And We will give temptation to you, with little fear, hunger, lack of wealth, soul and fruit. And give good news to people who are patient. (i.e) people who, when overtaken by calamity, say: Inna lillaabi wa innaa ilaibi raaji'uun. " 
kindness and patience (Ministry of Religion, 2016: 60). ${ }^{10}$ The virtue of Nasab is not merely an impact on social action, but directs the search for origin. Proposing to understanding human identity. Understanding of identity will introduce humans to the origin of everything, Allah Almighty. The introduction of the nature of the God almighty gives the burden of human obedience to obey all of Allah's commands and stay away from all His prohibitions. Obedience to Allah SW'T means obedience to the Messenger of Allah. As a messenger of Allah swt. Obedience to Allah SWT, and the Messenger of Allah. Guide the community to obedience to leaders.

Pua Macowa Bawalipu as a legitimate traditional leader through mocera tasi rituals carries the burden of spiritual and world exemplary, as well as his ratification. The exemplary burden pushed by Pua Macowa Bawalipu demands adequate capacity for understanding and practice of Shari'a in the midst of society. The attitude and actions of Pua Macowa Bawalipu are not solely at the normative level, but rather in the direction of inner and outer moral guidance. Pua Macowa Bawalipu is desirable to have patience, honesty, compassion, and noble character that is a role model for the community (Pua Siri, 2018). Through the mocera tasi ritual, the awareness of Pua Macowa Bawalipu and the entire community of Wotu was

${ }^{10} \mathrm{QS}$ al-'Ashr / 103: 1-3 states "For the sake of time. Indeed, man is truly in loss, except those who believe and do good deeds and advice advise them to obey the truth and advice advise that patience be tolerated. 


\section{Zulhas'ari Mustafa}

addressed to understand and carry out Shari'a teachings in order to fulfill worldly and spiritual benefits based on the objectives of the Shari'a.

Mocera tasi in the context of folk rituals relates to wealth as a support for human life to serve the God. The sea is a source of wealth for the people of Wotu. The pursuit of wealth in the sea in the traditional view of the Wotu community is not intended to exploit nature arbitrarily, but for the sake of human survival (Djati, 2018). The blessing of property for the people of Wotu is expected to be beneficial to worldly life and here after life. The enjoyment of assets acquired by humans in the sea should be grateful (Ministry of Religion, 2016: 256). ${ }^{11}$ Thanking the blessings of Allah Almighty is basically also a request for rebellion, because the expression Gratitude will avoid individuals or groups of people from doom or disaster (Tuse, 2018). The benefits of benefiting the people of Wotu are seen in increasing the appreciation of human relations with nature, the growing culture of gratitude in society, increasing motivation to learn in the community, alms living awareness in society, the relief of the community in earning a living, the motivation to do good and the relationship between friendship and togetherness are getting closer. The benefits appear to be related to worldly and spiritual benefits. Mocera ritual can also be a form of informal education for the entire community,

${ }^{11}$ QS Ibrahim / 14: 7 says "Dan (remember also), when your Lord declares; "Surely if you are grateful, surely We will add (favor) to you, and if you deny (My blessings), then My punishment will be very painful." 
especially the younger generation. The mocera tasi ritual through the changing times has been proven through pre the periodic community of Wotu according to the agreed time interval.

\section{The Coverage of the Benefits of Mocera Tasi}

The practice of mocera tasi, both as an adat ritual and as a folk ritual became part of the practice of customary institutions in Wotu. The adat ritual ratification of Pua Macowa Bawalipu must be performed in the ritual of mocera tasi. The abundance of spiritual and world authority over Pua Macowa Bawalipu can only be given by the Creator. According to Wotu's traditional perspective, humans cannot provide the validity of spiritual leadership towards someone. Spiritual and world leadership of Pua Macowa Bawalipu can only be obtained through an path directly before the Creator, witnessed by all elements of society. The election moment was chosen as the venue for ratification of traditional leadership based on the following reason. First, the sea has a vital role in the sustainability of the life of the Wotu community as a maritime society. Second, the sea was a vehicle for the presence of the first humans inhabiting Wotu's earth, which formed the Luwu civilization. The footsteps of the first human presence in Wotu reminded the community of origin or identity which led to the introduction of the Creator. Third, the sea is water. Apart from being an important need for human life, water is a human origin. Fourth, the vast expanse of the ocean touches the awareness of the smallness of man before the Creator. 
Awareness of the smallness of human beings before the Creator gave birth to the seriousness and solemnity of the perpetrators of the ritual of mocera tasi, especially the Pua Macowa Bawalipu who declared the oath of leadership before the Creator.

Parties who are considered to have competence, interests, and relevance to the existence of religious rituals in Wotu are the government, traditional institutions, cultural experts, scholars, the younger generation, and society. Bau Harase Pua Siri represents Bawalipu Wotu's miracle, stating that the importance of the mocera tasi ritual is maintained in the context of traditional rituals and folk rituals (Pua Siri, 2018). The development of the mocera tasi ritual left a message about the existence of the ethnic Wotu as the forerunner to the birth of the Luwu civilization. Wotu at the beginning of the emergence of the Luwu civilization was called Ale Luwu or Onto Luwu (center of Luwu). The people of Wotu also believe in the Islamic ancestry of Wotu much earlier than the Islamization of the unit of Luwu in Malangke by Datok Sulaiman. Pua Simpurussia as To Manurru in Wotu after Batara Guru is believed to have embraced Islam (Laedda, 2018). ${ }^{12}$ The contact of Islamic teachings with the ritual of

${ }^{12}$ There are two versions of Islamic acceptance in Wotu. Two versions of Islamic acceptance in Wotu remain earlier than in Pattimang. The first version of Islam refers to the Islamic Simpurusia Puata. The first version of Islam has not adopted the Shari'a in the Luwu customary system (Wotu). The second version of Islam has adopted the Shari'a in the Bawalipu system of customs. The Puata Simpurusia and Anakaji Period still occupies Wotu as the center of government. The Bau Cina government moved the center of government to Lelewawo. The 
prayer has been going on for centuries. If the mocera tasi ritual cannot be accepted by Sharia standards, then the mocera tasi cannot survive in the practices of the Kemacowaan Bawalipu that has adopted Islamic teachings. If the mocera tasi does not have important benefits for the community, then the practice of mocera tasi has long been lost in the tradition of the Wotu community. Running the mocera tasi ritual opens a historical sheet about the presence of Islam as a doctrine that is deeply rooted in the lives of the people of Wotu.

Muhammad Nur represented the activists and scientists from the Wotu indigenous community who considered the ritual of mocera tasi a tradition based on tradition that had structural and cultural ties in the indigenous community of Wotu (Nur, 2018). It can be stated that the conflict directly affected the heart of Wotu's life, because it came into contact with the structure and practice of indigenous people as Wotu's local residents. The local theological, cosmological, and ideological wisdom of society has declined in cultural actions through the ritual instrument of Mocera tasi. The teachings of Islam are absorbed in the theological views of the Wotu community in a very long time. Theological views influence cosmology and ideology so as to fill Wotu's local wisdom as a whole. The mocera tasi ritual is one of the cultural instruments that can directly touch local awareness of religious relations with cultural practices. Relation between religion and culture

government in Wotu is held by Old Smell as the eldest brother of Bau China. The Bawalipu congestion system is being carried out from the age of Old Smell. The adoption of Islam in the adat system occurred in the days of Macowa Amulla Pua Lemba Badidi. 
motivates the awakening of religious consciousness, so that religious nuances characterize the actions of individuals or society. Absorption of Islamic teachings can be seen in the slaughter of animals during worship, which is carried out according to the guidance of Islamic teachings. The recitation of the Holy Qur'an during the opening of the ceremony and the recitation of prayers, according to Islamic tradition, as the closing ceremony before the ritual of the Mangapacolo Raa was carried out giving an Islamic color to the ritual of Mocera tasi.

Ridwan Arsyad as the representative of the cultural section of the East Luwu Regency government gave high appreciation to the ritual of mocera tasi. The peculiarities of the mocera tasi ritual in the practice of the Wotu community are also characteristic of East Luwu. The benefits for the East Luwu district government are regional assets that must be maintained. The practical appreciation of the East Luwu district government is realized through moral, material, and recorded contributions to the mocera tasi ritual process (Arsyad, 2018). The educational side of the mocera tasi ritual motivates the community and district government to reexplore the local wisdom of the East Luwu community. The lessons learned from the negotiations are expected to provide mutual benefits between the Wotu community and the district government.

The village government through the Head of the Village of Lampenai positively appreciated the mocera tasi ritual. The community needs to preserve positive culture in the practice of life. Mocera tasi is one of the cultures carried out by the 
Wotu people. Preserving mocera tasi means strengthening the presence of Wotu ethnicity as a part of the Indonesian people (Bachrie, 2018). Cultural wealth, aspects of education, and inauguration of national identity place the mocera tasi ritual as a strategic tradition for culture-based development. Development on the basis of local culture will provide a continuity between the traditions of society and development. Continuity of development with local traditions gives birth to a sense of community ownership of the results of development. Mocera tasi as a culture becomes a part that cannot be eliminated from the people involved in it.

The relationship between mocera tasi and the teachings of Islam can be seen basically in a mutually complementary relationship. Islam in this case fills the theological foundation of mocera tasi. The theological foundation influences the world view of the Wotu community in relation to nature and fellow beings. The context of human relations with humans, humans and the environment, and humans and fellow creatures have an influence on some practices in the ritual of mocera tasi. Conformity with the Shari'a legitimizes the acceptance of the continuity of the ritual of the Mocera tasi. A spritual leader (Ulama) of the Uswatun Hasanah Islamic Boarding School, Kiyai Lalu Jalaluddin stated that the permissibility of religious rituals as long as it does not conflict with Islamic law (Jalaluddin, 2018). A complete assessment of the tradition of doctrine can be carried out by paying attention to the intentions, goals, and symbolic meanings in the procession of the process. Recognition of the Adat Stakeholders who 


\section{Zulbas'ari Mustafa}

handle marine affairs, M. Amin Anggoe explained that there was no other intention from the implementation of the negotiations other than the intention of expecting blessings and mercy from Allah SWT, both traditional rituals and folk rituals (Anggoe, 2018). Symbols and ritual tools are not at all dedicated as worship to other than Allah SWT. Practices, actions, readings, and ritual instruments are present as expressions of human closeness to nature and the creatures of God Almighty. Prerequisites and procedures for Sharia concerning slaughter are carried out in the mocera tasi tradition (Laluka, 2018). The acceptance of the elements of Islamic law in the series of mocera tasi processions marks the legitimacy of the Shari'a towards the ritual of mocera tasi as a good tradition ('urf șahih).

The benefit contained in the ritual of mocera tasi is at the level of häjiyat (necessity). Mocera tasi is one of the practices of local wisdom in the framework of ratifying leaders, expressing gratitude or rejecting reinforcements. The absence of the mocra tasi did not threaten or eliminate local leadership, but could disrupt the legitimacy of Pua Macowa Bawalipu as a traditional leader. Customary leadership can run without endorsement through the process of witnessing, but cultural obstacles always accompany the journey of leadership during Pua Macowa Bawalipu not yet ianca. ${ }^{13}$ The häjiyat category is also defined in the context of rejecting reinforcements and

${ }^{13}$ Ianca is a term used by Wotu community to swearing ceremony o Pua Macowa Bawalipu on Anca at the time of macera tasi. 
gratitude, because refusing activities or expressions of gratitude can be carried out on other occasions. The absence of corruption as an expression of gratitude or refusal of reinforcements does not threaten or eliminate property and livelihoods, but the total livelihood of the community will be disrupted without ever carrying out the ritual of mocera tasi. The continuation of Wotu's ethnic life in the midst of national life is in the important and urgent category (daririyyat). The main institution for enforcing the survival of the Wotu ethnic community is marriage. The marriage institution gave birth to a generation as a successor to the continuity of the Wotu ethnic community. Marriage relations gave birth to a system of kindship in the ethnic community of Wotu. The kindship system is increasingly widespread due to ongoing marriages. The extent of the kindship system requires social-cultural nodes that bind together all individuals and kindship groups. The socio-cultural knot is a role model that can guide the direction of people's lives both physically and mentally. The absence of socio-cultural nodes will adversely affect the integrity of kinship.

Traditional leadership institutions become manifestations of the presence of socio-cultural nodes. The traditional leadership institutions of the Wotu ethnic community are represented by the Kemacowaan Bawalipu led by Macowa Bawalipu or Pua Macowa. Based on the urgency of the presence of traditional leadership institutions, the presence of Pua Macowa was placed at the level of the maslahat darurizyyat in the stratification of maqüșid al-syari'ah. Another 
key element providing resilience for the survival of the community is related to food. Fulfillment of food is at the level of the masses of daruriyyat according to the level of maquașid al-syari'ah, because the absence of food will eliminate human life. Vital food sources for the Wotu ethnic community are related to the sea. Relations with the sea gave birth to Wotu's cultural tendency to maritime culture. Cultural instruments are carried out as a support for the existence of the Wotu ethnic community. The mocera tasi ritual is one of the maritime cultural instruments of the Wotu ethnic community. The loss of the mocera tasi ritual will not eliminate Wotu's ethnic entity, but it will bring difficulties in the process of community and fulfillment of life's needs. The difficulties due to the absence of the mocera tasi ritual are reasons for placing the ritual of mocera tasi at the level of the maslabat häjizyat in stratifying the objectives of the Shari'a. Mocera tasi is a cultural instrument of Wotu which serves as a support for the legitimacy of the leadership of the Macowa Bawalipu and guarantees the calm of the livelihood of the ethnic Wotu community.

The masculine content of the mocera tasi ritual is closely related to the category of preservation of the descent (hifz alnash) and preservation of the property (hifł al-mäl) in the order of al-kulliyat al-khams (five universal aspects). Al-kulliyat alkhams as the aim of establishing the Sharia (maqüșid al-syari'ah) recommends the order of preservation of five universal aspects on the basis of priority scale. The preservatioan of religion (hifz al-din) is in the first priority. The second priority 
under religion is occupied by preservation of the soul (hifz alnafs). Preservation of the reason (hifz al-aq) takes the third place. Preservation of the descent (hifz al-nash) occupies the fourth priority. Preservation of the property (hifz al-mäl) ranks fifth. The classification of socialization problems in the derivative and property maintenance category is due to the fact that the instrument as an instrument of cultural manifestation includes the moment of ratification of the leader, rejecting reinforcements, expressing gratitude. Endorsement of leadership is directly related to the function of maintaining the continuity of the Wotu ethnic generation. Preservating continuity of generation is in the category of descent preservation (hifz al-nash). The social benefits felt by the community strengthened the resilience of rituals in the practice of the Wotu ethnic culture.

\section{Conclusion}

The mocera tasi ritual is a maritime community ritual performed by the ethnic Wotu community. The mocera tasi rituals in the Wotu ethnic community were carried out to legitimize the leadership of the Macowa Bawalipu as adat leaders and expressions of gratitude or refusal to reinforce reinforcements. Mocera tasi as an instrument of Macowa Bawalipu ratification which is called indigenous ritual. Mocera tasi as an expression of gratitude and repulsion is then called folk ritual. Mocera tasi can survive in cultural practices, as rituals have benefits for the Wotu ethnic group. If connected with the purpose of Islamic law, mocera tasi provides benefits 
in the category of maintenance of social welfare and maintenance of the benefits of property. The degree of benefit of mocera tasi is at the level of häjizyat.

\section{REFERENCES}

Al-'Āmidī, Saif al-Dīn Abū al-Ḥasan 'Alī ibn Abi 'Alīi ibn Muḥammad. 1388 H. al-Iḥkàm fì Ușül al-Aḥkàm. juz 3. Bairūt: Muassasah al-Nūr

Agger, Ben. 1992. Cultural Studies as Critical Theory. cet. 1; London: The Falmer Press

Al-Būṭī, Muḥammad Sa’ìd Ramaḍān. 1992. Dawäbit alMașlahah fi al-Syari'ah al-Islamiyyah. The 6th edition; Bairūt: Muassasah al-Risālah

Al-Ghazālī, Abū Ḥamīd ibn Muḥammad ibn Muhammad. t. th. Al-Mustașfā min Ilmi al-Ușūll. t.tp: Nūr al-Ṡaqāâẫt al-Islāmiyyat

Ibn Khaldūn, 'Abd al-Raḥmān Abū Zaid Walī al-Dīn. 2004. Muqaddimah. Bairūt: Dār al-Fikr

Ministry of Religious Affairs. 2016. al-Qur'an dan Terjemahnya. Semarang: Toha Putera

Kuntowijoyo. 2001. Muslim Tanpa Masjid, Essai-Essai Agama, Budaya, dan Politike dalam Bingkai Strukturalisme Transendental. Bandung: Mizan 
Razak, Ischak. 2016. Negara Lumu Purba di Lembah Kalaena. Bungku: Murad Jalaluddin Books

Al-Syāṭibī, Abū Ishāq Ibrāhīm ibn Mūsā. t.th. al-Munvaffaqāt $f \grave{~}$ Ușül al-Syarīah. jilid I. juz II. Bairūt: Dār al-Kutub al'Ilmiyyah

Wahid, Abdurrahman. 2001. Pergulatan Negara, Agama dan Kebudayaan. Jakarta: Desantara 2005. Gus Dur Bertutur. ed. Alvian Muhammad dan Helmi Jacob. publishing I; Jakarta: Harian Proaksi

\section{Articles}

Zada, Khamami. dkk. 2003. "Islam Pribumi: Mencari Wajah Islam Indonesia". dalam Tashwirul Afkar, jumal Refleksi Pemikiran Keagamaan dan Kebudayaan, Edisi Number. 14, pp. 9-10

Opwis, F. 2017. "New Trends in Islamic Legal Theory: Maqāșid al-Sharīa as a New Source of Law", Die Welt des Islams, 57(1), 7-32

\section{Interviews, September - October 2018}

Anggoe, M. Amin. 10th September 2018. Traditional leader. Interview Wotu

Tuse. 30th September 2018. Community leader. Interview. Wotu

Laluka, Rustam. 25th September 2018. Traditional leader. Interview Wotu 
Putea, Ibrahim. 20th September 2018. Traditional leader. Interview Wotu

Syakhiruddin. 17th September 2018. Traditional leader. Interview Wotu

Pua Siri, Bau Harase. 28th September 2018. Pua Macowa Bawalipu. Interview. Wotu

Djati, Asroel. 15th September 2018. Young Figure. Intervien Wotu

Laedda, Darwis. 27th September 2018. Traditional leader. Interview Wotu

Nur, Muhammad. 30th September 2018. Wotu Culturist, Interview, Wotu

Arsyad, Ridwan. 1st Oktober 2018. Staff of Tourism and Culture Department. Regency of North Luwu Interview, Wotu

Bachrie, Zaenal. 05th Oktober 2018. Village leader of Lampenai. Interview. Wotu

Jalaluddin, Lalu. 08th Oktober 2018. Leader of Islamic Boarding School of Uswatun Hasanah. Interview. Wotu 